\title{
[論文】
}

\section{高温酸化物超伝導体 $\mathrm{La}-\mathrm{Sr}-\mathrm{Cu}-\mathrm{O}$ 系の 熱伝導率の測定}

\author{
根 本 栄 治 \\ 茨城工業高等専門学校、 $\bar{T} 312$ 勝田市中根深谷津 866 \\ 川下研介 \\ 東京工業大学工学部、干152 目黒区大岡山 $2-12-1$ \\ 井上明久、増本健 \\ 東北大学金属材料研究所、 $=980$ 仙台市片平 $2-1-1$
}

高温酸化物超伝導体の基本的な電気的および熱的物性の特徵を明確にすることは、超伝 導現象のメカニズムを明らかにするために重要である。本研究では、高温酸化物超伝導体 として重要な $\mathrm{La}^{-} \mathrm{Sr}-\mathrm{Cu}-\mathrm{O}$ 系酸化物の熱伝導率の温度依存性を定常平板比較法で測定し、 その熱伝導率特性を明らかにしている。

\section{1. 緒言}

ベドノルツとミュラー［1］により発見されたペロ ブスカイト構造をむつンタン系の酸化物超伝導体は、 約 $30 \mathrm{~K}$ に超伝導転移温度（Tc）を示す高温超伝導 特性を持つことが明らかにされている。この高温酸 化物超伝導体の発見を契機として約90KにTCをも つイットリウム系超伝遒体 $[2,3]$ が発見されたこ とは良く知られている。本研究では、ランタン系て 最も高いT c 丧むつL a - S r - C u - O系 [4]の 熱伝導率特性を明らかにするため、この試料の電気比 抵抗および熱伝章率を测定し、相互関係を明らかにす ることを目的としている。

\section{2. 試料}

本実験に用いた測定試料は、L a - S r - C u 系の 酸化物であり、その組成は $\mathrm{L} \mathrm{a}_{1.8} \mathrm{~S} \mathrm{r}_{\text {日. } 2 \mathrm{Cu} \mathrm{O}} \mathrm{O}_{4-u}$ である。 $\mathrm{L} \mathrm{a}_{2} \mathrm{O}_{3} 、 \mathrm{~S} \mathrm{r} \mathrm{C} \mathrm{O}$ およじ $\mathrm{CuO}$ 所定の 組成比に混合し、仮焼した後、円板状のペレットに加 圧、成形し、1 $1373 \mathrm{~K}$ で $3 \mathrm{~h}$ 焼結することにより作 製した。熱伝尊率の測定に用いた試料の形状は、直径 $1.046 \mathrm{~cm}$ 、厚如 $0.127 \mathrm{~cm}$ 、密度 3.473 g/ $\mathrm{c} \mathrm{m}^{3}$ であ。

\section{3. 転移温度测定}

\section{1 測定方法}

転移温度の测定は、作製した試料が超伝導体として の特性を備えているかどうかを確認するうえで重要で ある。本試料の電気比抵抗の温度依存性を 4 端子法 を用いて测定した。試料を直方体に切断し、電流を 流すための二端子と電圧を測定する二端子をカーボン ペーストを用いて試料に接続した。

\section{2 則定装置お゙よび実験結果}

比抵抗姑、温度制御可能な低温用クライオスタッ卜 を用いて、測定すべき試料の温度を変化させながら測

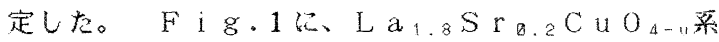
試料の比抵抗の測定値を常伝導状態にある4 $2 \mathrm{~K}$ の比 抵抗值 $\mathrm{R} n$ て無次元化した結果を示す。試料の比抵抗 は、42 Kから減少し始め、30.5 K で零となった。 本研究では、抵抗が零になる3 $30.5 \mathrm{~K}$ の温度を超伝 導転移温度とした。

\section{4. 熱伝導率湘定}

\section{1 测定方法}

高温超伝尊体 $\mathrm{L} \mathrm{a}_{1.8} \mathrm{Sr} 0.2 \mathrm{CuO}_{4-0}$ ○熱伝复率 を測定するため、純度、99.99\%の鉛を比較試料

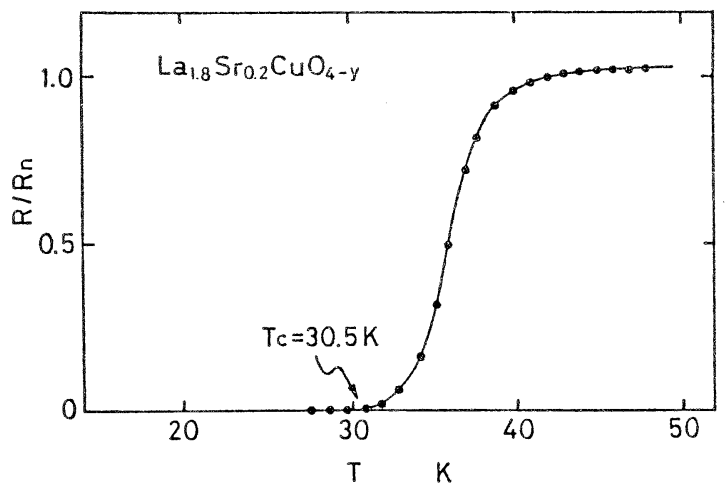

Fig.1 Temperature dependence of normalized electrical resistance $\mathrm{R} / \mathrm{Rn}$ of a $\mathrm{La}_{1.8} \mathrm{Sr}_{0.2} \mathrm{CuO}_{4-\mathrm{y}}$ oxide. 
とした定常平板比較法 [5] を採用した。

比較試料としての高純度鉛は、本測定試料の転移温 度 $30.5 \mathrm{~K}$ より低温の領域まで熱伝導率の大きな変 化を示さず、加工も容易であり、本測定法に適してい るので用いた。

熱伝導率入、試料の温度差 $\Delta T$ 、試料厚み $\Delta x$ とし、 比較試料の添字を $\mathrm{r}$ とすれば、酸化物超伝道体の熱伝 導率は、次式で与えられる。

$$
\lambda=\lambda r(\Delta T / \Delta x) r /(\Delta T / \Delta x)---(1)
$$

比較試料挹よび超伝導体試料の厚さは分かっているの で、比較試料と超伝導体試料の温度差を測定し、比較 試料の各温度に打ける熱伝導率を同一純度の鉛試料の T.P.R.C.のデー夕 [6] 加求めると、この式よ り本酸化物超伝導体の熱伝導率を得ることができる。

本方法の測定精度は、20 270 Kの温度範囲で SUS 304 在用いて較正したところ、文献値 [7] に対して $8.9 \%$ 以下でった。

\section{2 実験装置}

F i g.2 亿、本酸化物超伝導体の熱伝導率測定に 用いた実験装置を示す。この装置は、大阪酸素（株） 製のクライオミニ D 型冷凍機を、ステンレス製の極低 温用クライオスタットに組み込んだもので、測定試料 部の温度制御が容易であり、長時間一定の熱流場を作 り易く、熱物性測定に有用なので使用した。

この装置内は、低温下での熱の流入を防ぐため、空 気排気ボートより、6.67×1 $0^{-2} \mathrm{P}$ a 以下に常に 排気し、低温を保持している。酸化物超伝道体の熱 伝尊率を測定するための実験測定部は、定常比較法を 用いて熱伝樽率を測定するため、加熱用はくヒーター、 熱電対埋め込子用銅板 $(0.2 \mathrm{~mm})$ 、測定すべき超 伝導体試料、熱電対用銅板、鉛試料（直径 1.046 $\mathrm{cm}$ 、厚さ $0.233 \mathrm{~cm}$ )、および熱電対用銅板を 層状に配置し、低温接着剂、スタイキャスト 1266 で一定圧力を加えて接着した。

温度測定用熱電対としては、低温での熱起電力の直 線性に優机る金 $+0.07 \%$ 鉄対クロメル熱電対（線 径 $0.2 \mathrm{~mm}$ ）埶電対埋め込为銅板の中央部に取 り付け、低温接着剂で接着して用いた。本湘定装置 では、測定試料および標準試料の側面から、ふく射に よる熱損失が考えられるが、近接空間にアルミのふく 射しゃへい板を設けて、ふく射による熱損失を少なく している。また、超伝道体試料と熱電対用銅板の間の 接触熱抵抗㧍よび鉛の比較試料と熱電対用銅板の間の 接触熱抵抗は、各試料と銅板の温度差を白金一コバル 卜抵抗体で求めたところ0.005 K以下で、本冷凍機 の能力が、 $15 \mathrm{~K}$ で $1.5 \mathrm{~W}$ でるので、 $3 \times 10^{-7} \mathrm{~m}^{2}$
$\mathrm{K} / \mathrm{W}$ 以下となるため無視することできる。また、 試料中心と端部の温度差は、0.01 K以下で近似的 に一次元熱流場が実現しているので、本定常平板比較 法より超伝導体試料の熱伝導率が測定できる。

\section{3 実験結果}

本超伝導体の熱伝導率は、クライオミニ D 型冷涷機 を $1 \mathrm{~h}$ 加ら $2 \mathrm{~h}$ 程稼働し、測定試料を十分泠却した後、 はくヒーターに電流を流して、試料が定常状態に達し たあとで、測定した。温度の測定には、江藤電気

（株）製のパーソナル・データロガー、サーモダック 32 および (株) アドバンテスト製のデジタル温度計 T R $21144 \mathrm{H}$ 用い、G P - I B Kより日本電気

(株) 製のパーソナルコンピュータP C $98-V \mathrm{~m} 2$ へデータを取込み、式（1）より熱伝尊率を求めた。

熱伝道率測定時の超伝導体の両端面の温度差は、 $0.4 \sim 1.5 \mathrm{~K}$ の範囲にあり、この平均温度に対する 熱伝導率を求めた。

Fi g.3k、L a ${ }_{1.8} \mathrm{Sr}_{0.2} \mathrm{CuO}_{4-4}$ の熱伝樽率 の温度依存性を示す。本試料の熱伝導率は、1 $160 \mathrm{~K}$ の高温から温度が低下するにつれて緩やかに減少し、 転移温度 $30.5 \mathrm{~K}$ 過ぎたたりから急激に上昇し、 $21.7 \mathrm{~W} /(\mathrm{m} \cdot \mathrm{K})$ の極大值を示した後、温度の低

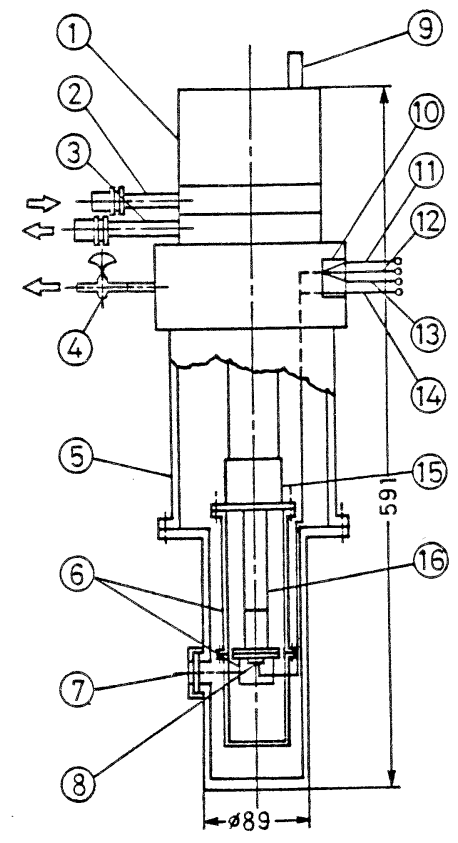

(1) Refrigerator

(2) High pressure gas supply

(3) Gas outlet

(4) To vacuum

(5) Outer cylinder

(6) Radiation shield

(7) Window

(8) Specimen

(9) Control terminal

(10) Gauge port

(11) Thermocouple 1

(12) Thermocouple 2

(13) Thermocouple 3

(14) Heater power supply

(15) 1-stage piston

(16) 2-stage piston

Fig.2 Experimental Apparatus. 
下と共に急速に減少する傾向を示している。この熱伝 導率の温度依存性の傾向は、高温超伝胹体である $\mathrm{Y}$ $\mathrm{B} a-\mathrm{C} u-O$ 系の熱伝導率の温度依存性 [8-1 0 ] と類似しており、高温酸化物超伝道体に共通した特徴 と考えられる。よって、酸化物の高温超伝道性に関 する理論の構築においては、Fi g.3に示した熱伝 導率の温度依存性を考慮に入れる必要があると思われ る。

\section{5. 結論}

本論文では、ランタン系で最も高い $\mathrm{T}$ c を示す $\mathrm{L} a-\mathrm{S} r-\mathrm{C} u-\mathrm{O}$ 系酸化物の比抵抗と熱伝等率 湘定し、次の結論を得た。

（1）高温超伝導体 $0 \mathrm{~L} \mathrm{a} 1.8 \mathrm{Sr}_{0.2} \mathrm{CuO}_{4-u}$ 酸化物の比抵抗を $20 \mathrm{~K}$ 少ら50Kの温度域で、ま 熱伝導率を、超伝導転移温度 $(T c=30.5 \mathrm{~K}$ ) を 含む $13 \mathrm{~K}$ から $160 \mathrm{~K}$ 範囲で測定した。

(2) 比抵抗は、温度が下がるにつれて徐々に小 さくなり、42 Kから急激に低下し $30.5 \mathrm{~K}$ で零抵 抗を示し、30.5 K に超伝導転移温度を有していた。

（3）熱伝導率は、160 Kから温度が低下する につれて緩やかに減少し、転移温度 $30.5 \mathrm{~K}$ 経過 したあたりから熱伝導率が急激に上昇し、約 $23 \mathrm{~K}$ で 熱伝渞率の極大值を示した後、さらに温度が下がるに つれて、大きく低下する傾向を示すことが明かとなっ to

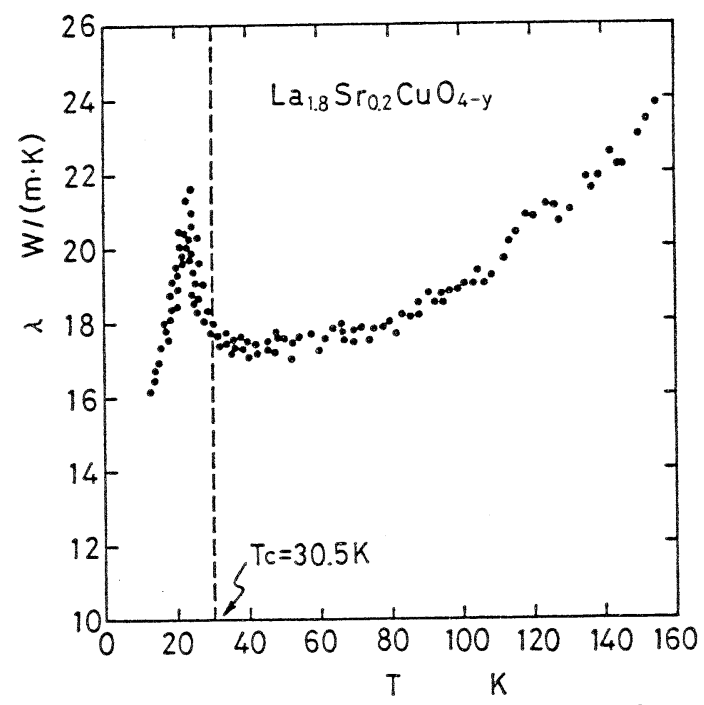

Fig.3 Temperature dependence of thermal conductivity of a $\mathrm{La}_{1.8} \mathrm{Sr}_{0.2} \mathrm{CuO}_{4-\mathrm{y}}$ superconductor. The zero-resistance temperature, $30.5 \mathrm{~K}$, is also shown in this figure.

\section{文献}

[1] J.G.Bednorz, K.A.Muller; Z. Phys. B-Condensed Matter,64(1986)189/193.

[2] M.K.Wu,J.R.Ashburn, C.J.Torng, P.H. Hor, R.L.Meng, L.Gao, Z.J.Huang, Y.Q.Wang, C.W.Chu; Phys.Rev.Lett., $58(1987) 908 / 910$

[3] P.H.Hor,L.Gao,R.L.Meng, Z.J.Huang, Y.Q.Wang, K.Forster, J.Vassilious, C.W.Chu, M.K.Wu, J.R.Ashburn, C.J.Torng; Phys.Rev.Lett., $58(1987) 911 / 912$.

[4] R.J.Cava,R.B.van Dover,B.Batlogg, E.A.Rietman; Phys.Rev.Lett., $58(1987) 408 / 410$.

[5] 根本栄治,川下研介; 機論, 53(1987)2181/2186。

[6] Y.S.Touloukian, R.W.Powell, C.Y.Ho, P.G.Klemens," Thermophysical Properties of Matter "vol.1(1970), p.175, IFI/Plenum.

[7] reference [6],p.1160.

[8] 根本栄治,川下研介, 井上明久, 増本健; 機論投稿中。

[9] D.T.Morel1i,J.Heremans,D.E.Swets; Phys.Rev.B,36(1987)3917/3919.

[10] C.Uher,A.B.Kaiser; Phys.Rev.B, $36(1987) 5680 / 5683$.

Thermal Conductivity of a $\mathrm{La}_{1.8} \mathrm{Sr}_{0.2} \mathrm{CuO}_{4-\mathrm{y}}$ Superconductor

\author{
Eizi Nemoto \\ Dept. of Mech. Eng., \\ Ibaraki College of Tech. \\ 866, Nakane, Katsuta, \\ Ibaraki, 312 Japan \\ Kensuke Kawashimo \\ Dept. of Mech. Eng., \\ Tokyo Institute of Tech. \\ 2-12-1, Ookayama, Meguroku, \\ Tokyo, 152 Japan \\ Akihisa Inoue \\ Institute for Materials \\ Research, \\ Tohoku Univ. \\ Katahira 2-1-1, Sendai \\ 980 Japan \\ Tsuyoshi Masumoto \\ Institute for Materials \\ Research, \\ Tohoku Univ. \\ Katahira 2-1-1, Sendai \\ 980 Japan
}

This paper attempts to clarify the significance of the thermal conductivity of a $\mathrm{La}_{1.8} \mathrm{Sr}_{0.2} \mathrm{CuO}_{4-\mathrm{y}}$ superconductor. The onset and zero-resistance temperature of the La-Sr-Cu-O superconductor were $42 \mathrm{~K}$ and $30.5 \mathrm{~K}$, respectively. The thermal conductivity decreased gradually with decreasing temperature for the normal conductive state in the temperature range of 160 and $40 \mathrm{~K}$, i.e., $23.8 \mathrm{~W} /(\mathrm{m} \cdot \mathrm{K})$ at $160 \mathrm{~K}$ and $17.4 \mathrm{~W} /(\mathrm{m} \cdot \mathrm{K})$ at $40 \mathrm{~K}$. In 
the superconducting transition range, the thermal conductivity increased very greatly with decreasing temperature a maximum value of $21.7 \mathrm{~W} /(\mathrm{m} \cdot \mathrm{K})$ at $23 \mathrm{~K}$ and decreased greatly with decreasing temperature. A similar sharp peak of the thermal conductivity has been found for $Y$-based oxide superconductors and hence it is concluded that the sharp increase of thermal conductivity is a common characteristic for high transition temperature (TC) oxide superconductors.

(Received on Oct. 14, 1987)

(Accepted for Publication on Jan. 26, 1988)

\section{「熱工学の研究動向と熱技術の進展」 刊行について}

日本学術会議の熱工学研究連絡委員会では過去 3 年 間、広い分野にまたがる熱工学の研究動向について、 総合的分析を加え、討議を行なってきた。今回その成 果として、長期的な研究推進に示唆を与えるような総 合的レピューを刊行することとなった。取り上げられ たのは然焼、伝熱それに熱物性の3分野である。先端 科学技術の発展においてこれら 3 分野がどういう役割 を果たすか、そのためにどのような研究を行なう必要 があるかを、ごく压縮した形で展望している。

内容は、爇工学全般にわたる第二次大戦後の流れに

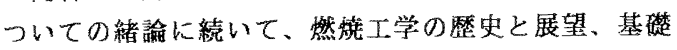
研究の動向、燃焼に関する総合的あるいは長期的課題 や新技術関連の課題、伝熱研究と伝熱技術の過去の経 緯、現状ならびに展望、将来課題、そして熱物性研究
の経緯と現状、研究動向、熱物性分野の将来展望、新 技術関連課題などの動向などについて記述している。 数値的な資料は含まれていないものの、熱工学白書と も称すべきものを目眐として編集されている。これら 3 分野における 36 名のエキスパートの共同討議を経 ている点にも意義があるといってょいであるう。

日本学街協力財団より、本年6月頃に刊行される予 定であり、全体の頁数は䄪 150 頁、定価 1000 円 である。

本書の入手をご希望の方は、あるいは内容について ご質問がお有りの方は、日本熱物性研究会事務局、ま たは長島 昭（瞢大理工学部、044-63-114内線3168） までお問い合わせ下さい。 